\title{
Phylogeny of Coussareeae (Rubioideae, Rubiaceae)
}

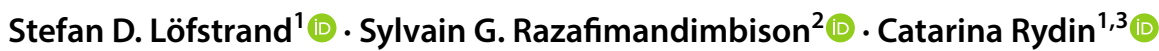

Received: 21 November 2018 / Accepted: 13 February 2019 / Published online: 20 March 2019

(c) The Author(s) 2019

\begin{abstract}
Coussareeae are a Neotropical clade of morphologically heterogeneous plants in the subfamily Rubioideae of the coffee family (Rubiaceae). The tribe encompasses about 330 species assigned to ten genera: Bradea, Coccocypselum, Coussarea, Cruckshanksia, Declieuxia, Faramea, Heterophyllaea, Hindsia, Oreopolus, and Standleya. Historically, the genera of Coussareeae have rarely been considered closely related, and the widely defined Coussareeae were delimited based on molecular systematics without proposed morphological synapomorphies. In order to assess the tribe's monophyly, as well as the generic limits, infrageneric relationships, and suprageneric relationships, multiple specimens per genus were sampled whenever possible and analyzed using multiple molecular loci with the Bayesian and maximum likelihood methods. The results of the phylogenetic analyses (all genera represented by multiple terminals are monophyletic, all genera are resolved with respect to each other, and three major suprageneric clades are resolved), coupled with herbarium and literature studies, were used to identify potential synapomorphic features. Non-molecular diagnostic features remain elusive for Coussareeae as a whole, but we have identified multiple diagnostic features and potential synapomorphies for each of the three major suprageneric clades: (1) Coussarea and Faramea (e.g., porate pollen grains with annuli bordering the pores); (2) Bradea, Coccocypselum, Declieuxia, Hindsia, and Standleya (e.g., colporate pollen grains with complex reticulate tecta); and 3) Cruckshanksia, Heterophyllaea, and Oreopolus (e.g., chartaceous, loculicidal capsules). The latter clade, distributed in different biomes of the Andes, is sister to the former two, both widely distributed in the Neotropics.
\end{abstract}

Keywords Coccocypseleae $\cdot$ Coussareeae $\cdot$ Cruckshanksieae $\cdot$ Molecular phylogenetics $\cdot$ Rubiaceae $\cdot$ Synapomorphy

\section{Introduction}

Coussareeae sensu Bremer and Manen (2000) with subsequent amendments by Robbrecht and Manen (2006) and Delprete and Jardim (2012) belong to the subfamily Rubioideae of Rubiaceae. The tribe includes all members of the tribes

Handling editor: Livia Wanntorp.

Electronic supplementary material The online version of this article (https://doi.org/10.1007/s00606-019-01572-8) contains supplementary material, which is available to authorized users.

Stefan D. Löfstrand

stefan@lofstrand.net

1 Department of Ecology, Environment and Plant Sciences, Stockholm University, 10691 Stockholm, Sweden

2 Department of Botany, Swedish Museum of Natural History, Box 50007, 10405 Stockholm, Sweden

3 The Bergius Foundation, The Royal Swedish Academy of Sciences, Box 50005, 10405 Stockholm, Sweden
Coccocypseleae sensu Piesschaert et al. (2000), Coussareeae sensu Hooker (1873), and Cruckshanksieae sensu Andersson and Rova (1999), as well as Bradea (formerly assigned to Rondeletieae) and Standleya (formerly assigned to Hedyotideae, now Spermacoceae; Robbrecht 1988; Delprete and Jardim 2012).

Bremer (1996), based on $r b c \mathrm{~L}$ sequence data, first suggested a close relationship between Coccocypselum and Coussarea, followed by Andersson and Rova (1999), who revealed close relationships of Cruckshanksieae sensu Hooker (1873; represented by Oreopolus), Heterophyllaea (formerly Cinchoneae, Cinchonoideae), Coccocypseleae sensu Bremekamp (1952; i.e., Coccocypselum), Declieuxia (formerly Psychotrieae), Hindsia (formerly Cinchoneae or Hedyotideae), and Coussareeae sensu Hooker (1873; i.e., Coussarea and Faramea). Shortly thereafter, Bremer and Manen (2000) found a close relationship between Coussarea, Coccocypselum, Declieuxia, Cruckshanksia, Faramea, and Oreopolus in their analyses of Rubioideae. In order to resolve many non-monophyletic tribes identified in their 
analyses, Bremer and Manen (2000) formally adopted a wide definition of Coussareeae. They were, however, cautious in their delimitation of the tribe and chose to only list the genera included in their study, but mentioned Heterophyllaea and Hindsia as probable members of the tribe, based on the results of Andersson and Rova (1999). Bremer and Manen's (2000) taxonomic decision to merge Coccocypseleae and Cruckshanksieae in Coussareeae was subsequently endorsed by Robbrecht and Manen (2006), who additionally amended the tribe's limits to formally include Hindsia and Heterophyllaea. This broadly delimited Coussareeae is widely accepted by the contemporary Rubiaceae community and consistently recovered as a natural group and one of the early diverging lineages in Rubioideae (e.g., Bremer and Eriksson 2009; Rydin et al. 2009a; Wikström et al. 2015). Bradea and Standleya were later tentatively assigned to Coussareeae sensu Bremer and Manen (2000) by Delprete and Jardim (2012), based on their morphological similarities with Coccocypselum, Declieuxia, and Hindsia, as well as unpublished molecular data for Standleya (Oliveira 2012).

Hence, Coussareeae currently encompass approximately 330 species assigned to ten genera (Bremer and Manen 2000; Robbrecht and Manen 2006; Delprete and Jardim 2012; Tropicos, 2018): Bradea (6 spp.), Coccocypselum ( 20 spp.), Coussarea ( 100 spp.), Cruckshanksia (7 spp.), Declieuxia ( 30 spp.), Faramea ( 150 spp.), Heterophyllaea (2 spp.), Hindsia (11 spp.), the monospecific Oreopolus, and Standleya (5 spp.). The monophyly of this widely defined Coussareeae is, however, yet to be tested as Bradea has not previously included in any molecular phylogenetic study, and the other nine genera have yet to be included in the same phylogenetic analyses. Additionally, none of the tribe's genera have ever been represented by more than a couple of terminals in phylogenetic studies (e.g., Bremer 1996; Andersson and Rova 1999; Rydin et al. 2009a). Consequently, neither the monophyly of the tribe, nor the generic limits, infrageneric relationships, and suprageneric relationships has yet been tested.

As might be expected by their complex taxonomic history, Coussareeae are morphologically heterogeneous and difficult to characterize using non-molecular characters (e.g., Bremer and Manen 2000; Robbrecht and Manen 2006). Their growth habit is diverse, ranging from herbs (Coccocypselum, Cruckshanksia, Standleya) to subshrubs or small shrubs (Bradea, Cruckshanksia, Declieuxia, Hindsia, Oreopolus) and medium to large shrubs, treelets, and trees (Coussarea, Faramea, Heterophyllaea; Schumann 1891). Inflorescences are highly variable even within genera, but they are typically variations of axillarily, supraaxillarily, and/or terminally inserted cymes (Schumann 1891; Taylor et al. 2004). The inflorescences of some Coussarea and Faramea species are showy (similarly colored to the corolla and calyx) and/ or bear enlarged, showy bracts (Faramea only, e.g., Taylor et al. 2004). Flowers are hermaphroditic or rarely dioecious (Bawa and Beach 1983; Taylor et al. 2004; Maruyama et al. 2010) and mostly heterostylous, with white, blue, or yellow corollas (Schumann 1891; Taylor et al. 2004); some species additionally have showy calycophylls (Cruckshanksia, Taylor 1996) or petaloid calyx lobes (Faramea, Taylor et al. 2004). There is also a wide range of fruit types represented in the tribe (Hooker 1873; Schumann 1891; Taylor 1996; Jardim and Costa 2015; Oliveira and Sobrado 2016): blue, baccate schizocarps with few-seeded, hollow mericarps (Declieuxia); blue, hollow, multi-seeded baccate indehiscent fruits (Coccocypselum); green-white-yellow (Coussarea) or dark blue-purple-black (Faramea) 1(-2)-seeded drupes; lignified, septicidal capsules (Bradea, Hindsia, Standleya); and chartaceous, loculicidal capsules (Cruckshanksia, Heterophyllaea, Oreopolus). With the tribe's members displaying such high level of morphological diversity, it is hardly surprising that the eight genera were formally assigned to several distantly related tribes in pre-molecular classifications of Rubiaceae (e.g., Hooker 1873; Verdcourt 1958; Bremekamp 1966).

The tribe is widely distributed in the Neotropics, but its genera are often restricted to specific biomes in geographically narrow regions. Cruckshanksia, Heterophyllaea, and Oreopolus are confined to different arid regions in Chile and Argentina, whereas Bradea, Hindsia, and Standleya together with most Declieuxia spp. and Coccocypselum spp. are endemic to different biomes in southeastern Brazil (Schumann 1891; Taylor 1996; Tropicos 2018). Coussarea, Faramea, some Coccocypselum spp. and a few Declieuxia spp. show wider distributions, ranging from central Mexico to southern tropical region of South America (Tropicos 2018; Govaerts et al. 2018).

This study aims to produce a robust phylogeny of Coussareeae by utilizing a dense taxon sampling and several chloroplast and nuclear ribosomal loci to assess the tribe's current circumscription and generic limits and relationships. With a better understanding of the tribe's phylogenetic relationships, synapomorphic and diagnostic features identified from investigations of herbarium sheets and literature studies will be discussed for the tribe and its suprageneric clades.

\section{Materials and methods}

\section{Taxon sampling and laboratory procedures}

The taxon sampling was aimed to represent all genera traditionally and/or currently associated with Coussareeae and a representative set of other tribes in Rubioideae (Online Resource 1; Wikström et al. 2015). Attempts were made to include multiple terminals for all Coussareeae genera, 
but this proved unfruitful with the material at hand for both Oreopolus and Standleya (the other sampled specimens did not amplify for any of the selected loci).

Information from six loci was utilized for this study; four chloroplast (cDNA) loci: $a t p \mathrm{~B}-r b c \mathrm{~L}$ intergenic spacer (IGS), $n d h \mathrm{~F}, r p s 16$ intron, and $t r n \mathrm{~L}-\mathrm{F}(t r n \mathrm{~L}$ gene and $t r n \mathrm{~L}-t r n \mathrm{~F}$ IGS); and two nuclear ribosomal DNA (rDNA) loci: ETS (external transcribed spacer) and ITS (internal transcribed spacer 1-5.8S gene-internal transcribed spacer 2). The 325 sequences produced for the present study were supplemented by sequences downloaded from GenBank. All GenBank accession numbers are presented in Online Resource 1.

Extraction and polymerase chain reaction (PCR) protocols follow the standard procedures described in Bremer et al. (2002), Kårehed and Bremer (2007), and Rydin et al. (2009b). The atpB-rbcL IGS was amplified with "rbcL5'R" and "atpB5'R" (Rydin et al. 2009b); ndhF was amplified with "2F", "1000R", "720F", “1700R", "1320F", and "2280R" (Rydin et al. 2009b); the rps16 intron was amplified with "F" and "2R" (Oxelman et al. 1997); trnL-F was amplified with "820F", "1250F", "1880F", and "2670R" (Rydin et al. 2009b) with the addition of "iR" (Bremer et al. 2002) and "d" (Taberlet et al. 1991); ETS was amplified with "Erit-F" (Negrón-Ortiz and Watson 2002) and "18SE" (Baldwin and Markos 1998); and ITS was amplified with "4R" and "Leu1" (White et al. 1990). Sequences were assembled in Geneious ver. 10.1.2 (http://www.geneious. com; Kearse et al. 2012). Ambiguous base assignments were coded as missing information.

\section{Sequence alignment and phylogenetic analyses}

Sequences were aligned in MUSCLE ver. 3.8.31 (default settings; Edgar 2004) and manually corrected in Mesquite ver. 3.31 (Maddison and Maddison 2017) where the algorithm produced unlikely alignment positions. The concatenated sequence alignments are available in Online Resource 2.

The best-fitting nucleotide substitution models were selected for each locus under the corrected Akaike information criterion (AICc) as implemented in jModelTest 2 ver. 2.1.10 (Darriba et al. 2012). A generalized time-reversible model with gamma distribution $(\mathrm{GTR}+\Gamma)$ was selected for $a t p \mathrm{~B}-r b c \mathrm{~L}$ IGS, ETS, and ITS, while a generalized time-reversible model with inverted gamma distribution $(\mathrm{GTR}+\mathrm{I}+\Gamma)$ was chosen for $n d h \mathrm{~F}, r p s 16$, and $t r n \mathrm{~L}-\mathrm{F}$.

Individual loci and concatenated datasets (cDNA, rDNA, and cDNA + rDNA) were analyzed using Bayesian Markov chain Monte Carlo (MCMC) inference as implemented in MrBayes ver. 3.2.5 (Ronquist et al. 2012). The Bayesian analyses comprised two runs of four MCMC chains each that were run for $10^{7}$ generations, sampling trees and parameters every thousandth generation (25\% relative burn-in). Convergence of the MCMC chains was confirmed (standard deviation of split frequencies $\leq 0.01$ ) in the post-burn-in generations (Ronquist et al. 2012) and supported by minimum estimated sample sizes $\geq 100$ and potential scale reduction factors approaching 1.000 (Gelman and Rubin 1992; Ronquist et al. 2012). These samples were used to calculate Bayesian posterior probabilities. For concatenated datasets, each locus was treated as a separate, unlinked partition with individually assigned nucleotide substitution models. All other parameters were left at default settings.

No supported topological conflict, i.e., Bayesian posterior probability (PP) $\geq 0.95$ (Erixon et al. 2003), was detected in preliminary phylogenetic analyses of individual loci or the respective concatenated cDNA and rDNA datasets. Hence, all loci were concatenated in one partitioned matrix for a final analysis. Consensus trees resulting from the concatenated analyses were rooted on Luculia grandifolia (Wikström et al. 2015).

To supplement the Bayesian analyses, the concatenated cDNA + rDNA dataset was performed under the maximum likelihood criterion using RaXML ver. 8 (Stamatakis 2014). The dataset was analyzed unpartitioned under the GTR $+\mathrm{G}$ model using rapid bootstrapping. The results of 1000 bootstrap replicates were plotted on the best scoring tree. Maximum likelihood bootstrap support (ML) $\geq 70$ is considered supported (Erixon et al. 2003).

\section{Morphological assessment}

Herbarium specimens of all Coussareeae genera were examined at the Natural History Museum of Denmark Herbarium (C), Missouri Botanical Garden Herbarium (MO), New York Botanical Garden Herbarium (NYBG), and Swedish Museum of Natural History Herbarium (S). A broad literature review of the morphology, palynology, and karyology in the tribe was performed. A list of identified diagnostic and potentially synapomorphic characters for the suprageneric lineages is presented in Table 1. A scored datum represents the genus' common states and may not include all possible forms represented in the genus. Some structures were deemed unsuitable for interpreting the suprageneric relationships in the tribe. For instance, leaf, stipule, and inflorescence morphology are highly variable and of unlikely systematic importance for the purpose of identifying clades (e.g., Müller Argoviensis 1881; Schumann 1891; Taylor et al. 2004). Similarly, the androecium is always isomerous with the (actinomorphic) corolla lobes, the stamens are always inserted between the petals, and the gynoecia are always bilocular (albeit sometimes incompletely septate) and inferior; these structures are, hence, of little interest here (e.g., Schumann 1891). In this study, the color blue includes purple, and pale blue includes pale lilac. Additionally, the 


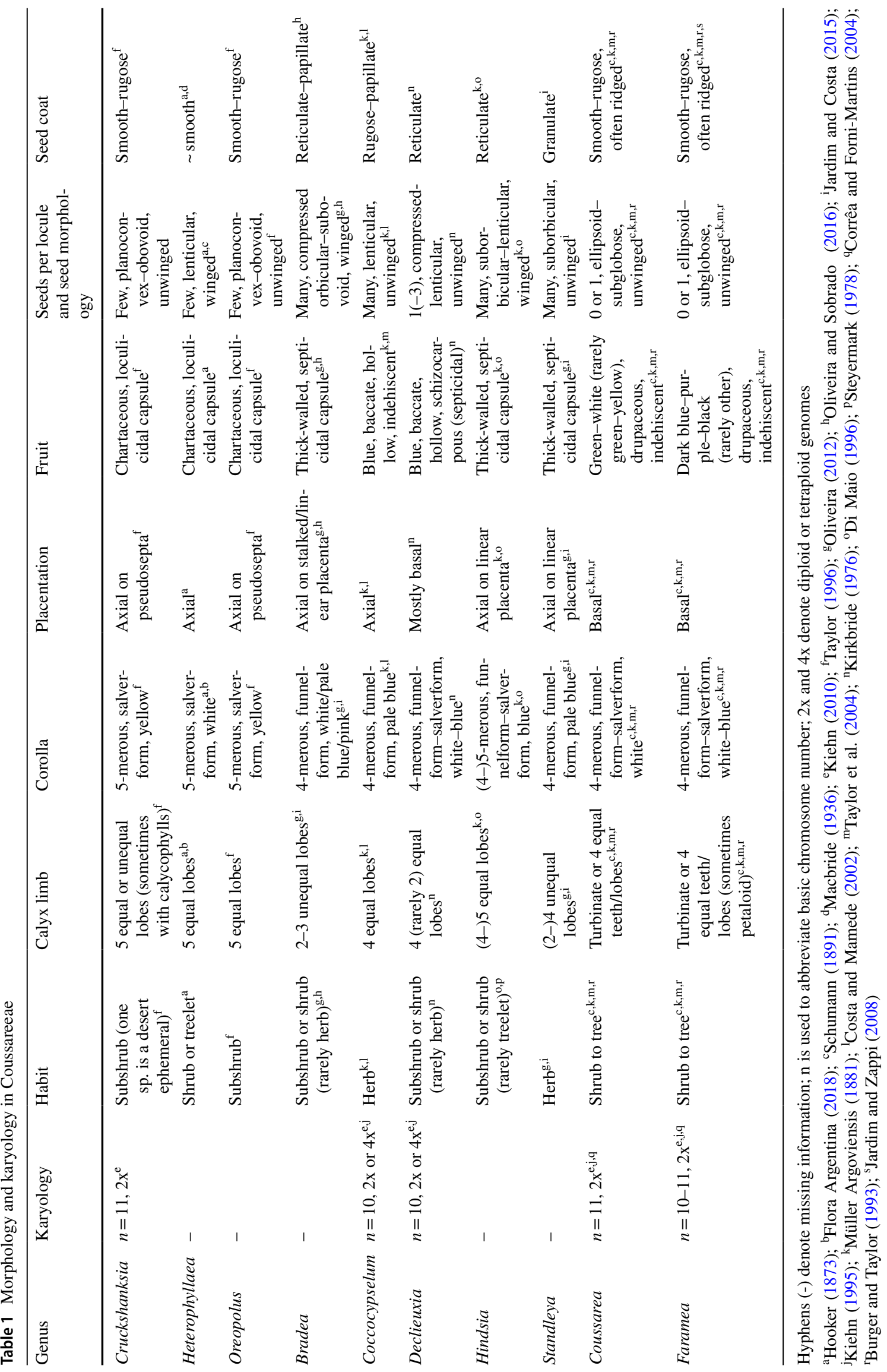


corollas of Heterophyllaea are abaxially purple-tinged, but adaxially white; they are here considered to be white.

\section{Results}

Results of the concatenated cDNA + rDNA analyses are presented in Fig. 1; the Bayesian and maximum likelihood analyses support the same topology (i.e., showing no support for the few discordant nodes). Consensus trees from the Bayesian analyses of the concatenated cDNA dataset and the concatenated rDNA dataset are available as electronic supplements (Online Resources 3 and 4).

Coussareeae form a monophyletic group (PP 1.00, ML 100), sister to a clade comprising the Psychotrieae and Spermacoceae alliances (PP 1.00, ML 81). Within the tribe, all genera represented by more than one species are resolved as monophyletic (PP 1.00 and ML 100, respectively). The genera are resolved in three major clades: (1) the Cruckshanksia clade (PP 1.00, ML 100) with Heterophyllaea as sister to Oreopolus and Cruckshanksia (PP 1.00 and ML 100, respectively); (2) the Coccocypselum clade (PP 1.00, ML 100) with Hindsia and Declieuxia (PP 1.00, ML 99) sister to a clade formed by Coccocypselum as sister (PP 1.00, ML 100) to Bradea and Standleya (PP 1.00, ML 99); and (3) the Coussarea-Faramea clade (PP $1.00, \mathrm{ML} 100)$. The two latter clades are sister groups (PP 1.00 , ML 100), consequently making them sister to the Cruckshanksia clade (PP 1.00, ML 100).

Our literature studies reveal that species of Coussareeae have basic chromosome numbers of 10 (Coccocypselum, Declieuxia, Hindsia), 11 (Coussarea, Cruckshanksia), or variable between 10 and 11 (Faramea). The karyology is to date unknown for Bradea, Heterophyllaea, Oreopolus, and Standleya. The most investigated species are diploid, but tetraploidy has been reported in Coccocypselum and Declieuxia (Table 1).

Their habit is mostly shrubby (including subshrubs) or arborescent, but Coccocypselum and Standleya are strictly herbaceous, Cruckshanksia pumila is a desert ephemeral, and perennial herbs are represented in Bradea and Declieuxia (Table 1; S. Löfstrand personal observation). Arborescent habit is mainly restricted to Coussarea and Faramea, but treelets occur also in Heterophyllaea and Hindsia (Table 1).

Flower morphology is largely consistent in the tribe, but, e.g., the calyx limb shows considerable variation; truncate calyces are only described for Coussarea and Faramea, but also in these genera the calyces are often denticulate or lobed (Table 1; S. Löfstrand personal observation). The number of calyx lobes is variable, but mostly isomerous with the corolla; the lobes are of-more or less-equal size in most genera, but generally unequal in
Bradea and Standleya and some species of Cruckshanksia (Table 1; S. Löfstrand personal observation). Some Cruckshanksia species present showy calycophylls and some Faramea species display petaloid calyces, but the traits follow no apparent phylogenetic patterns. The corolla tubes are funnelform to salverform: Cruckshanksia, Heterophyllaea, and Oreopolus all have clearly salverform corollas, whereas those of Bradea, Coccocypselum, and Standleya are clearly funnelform (Table 1; S. Löfstrand personal observation), and those of Coussarea, Declieuxia, Faramea, and Hindsia are more variable. The corollas are mostly tetramerous (Bradea, Coccocypselum, Coussarea, Faramea, Standleya) or pentamerous (Cruckshanksia, Heterophyllaea, Hindsia, Oreopolus; Table 1). The corollas of most species are in hues of white to blue/purple, but two genera stand out in displaying yellow corollas (Cruckshanksia, Oreopolus; Table 1). The placentation is mostly axial (Table 1), but basal in Coussarea, Faramea, and most Declieuxia. The placentae vary in shape: basal and miniscule bearing single ovules (Coussarea, Declieuxia, Faramea), extending along the fruit axis (Coccocypselum, Heterophyllaea), stalked/linear (Bradea, Hindsia, Standleya), or forming pseudosepta (Cruckshanksia, Oreopolus).

The fruits are capsular or baccate (generally considered drupaceous in Coussarea and Faramea) and spongy, fleshy, or leathery (rarely fibrous/dry; Table 1). Capsular fruits are either thick-walled and septicidal (Bradea, Hindsia, Standleya), or chartaceous and loculicidal (Cruckshanksia, Heterophyllaea, Oreopolus; Table 1; S. Löfstrand personal observation). Fruits of Declieuxia are septicidal with-more or less-fleshy to leathery schizocarps. Seeds are variable in shape and seed coat structure, but ridged seeds are, unlike in other Coussareeae, sometimes present in Coussarea and Faramea (Table 1). The number of seeds varies from few to many, but Coussarea and Faramea are generally single seeded (sometimes two seeded), through abortion of one ovule during development; they therefore have single-seeded fruits despite being structurally bilocular and biovulate (Table 1; S. Löfstrand personal observation).

Pollen grains are typically tricolporate and spheroidal (Bradea, Cruckshanksia, Coccocypselum, Declieuxia, Hindsia) or 2-4 porate and oblate-suboblate (Coussarea, Faramea; Table 2). Unlike in other Coussareeae, the pollen apertures of Coussarea and Faramea are bordered by annuli. The sexine sculpting is simple reticulate (Cruckshanksia), tectate-perforate-microreticulate (Coussarea), regulate (Faramea), or complex reticulate (Bradea, Coccocypselum, Declieuxia, Hindsia). The pollen morphologies of Heterophyllaea, Oreopolus, and Standleya have not yet been investigated. 


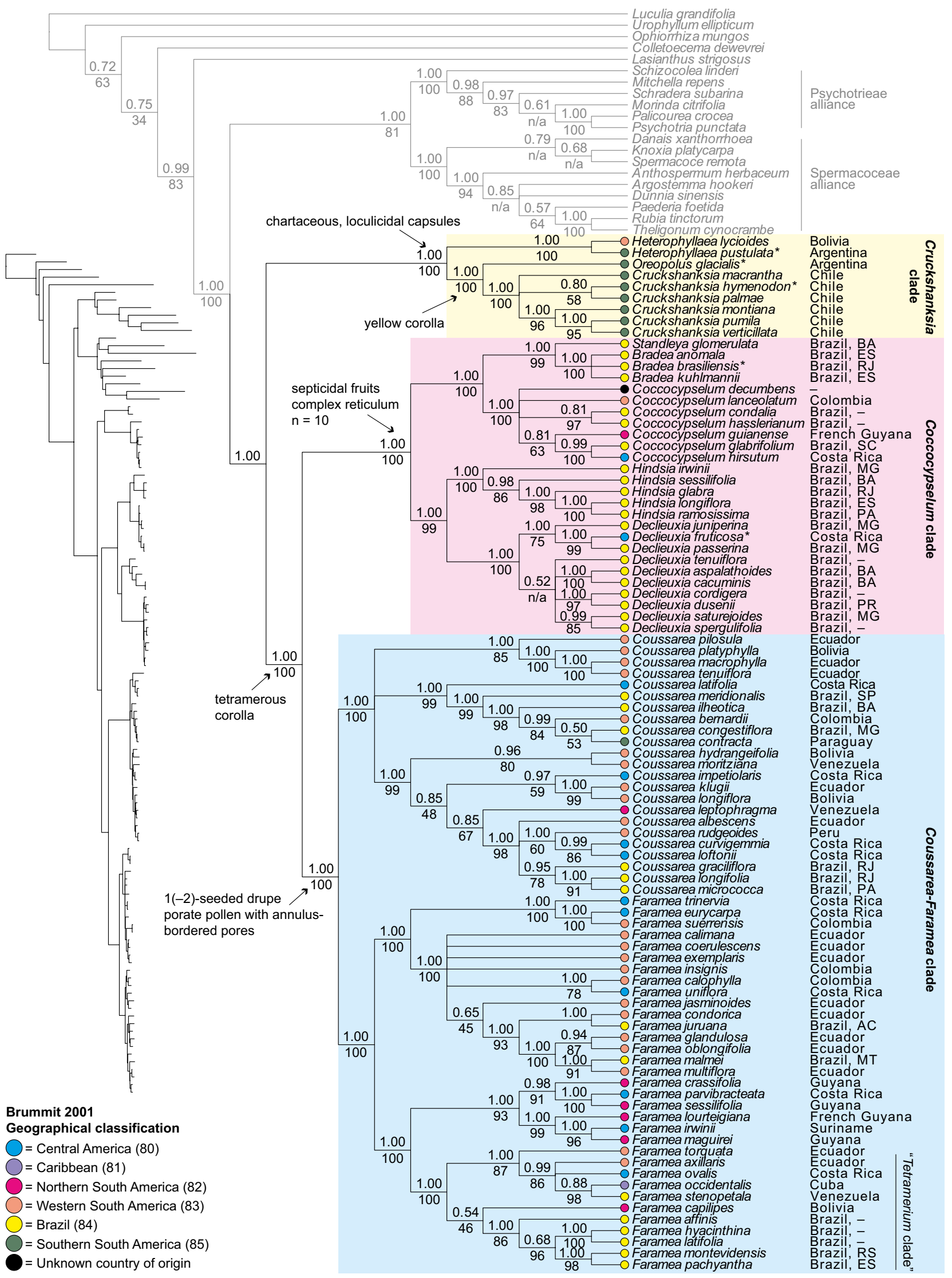


४Fig. 1 Bayesian 50\% majority rule consensus cladogram. Node support is presented to the left of each node (Bayesian posterior probabilities above; maximum likelihood bootstrap values below). $\mathrm{n} / \mathrm{a}$ is used where the corresponding node is neither present, nor opposed by the maximum likelihood analysis results. Coussareeae as here defined are displayed in black, whereas closely related taxa and outgroups are displayed in faded gray; suprageneric clades discussed in the text are marked by colored boxes. To visualize relative branch lengths, a phylogram without node labels and terminal labels is presented to the left. At the terminals, colored circles show the specimen's biogeographic origin as delimited by Brummit (2001); biomes are not accounted for. Asterisks (*) denote that the taxon includes the type of the genus. The specimen's country of origin (and state for most Brazilian collections) is presented to the right of the taxon name. Hyphens (-) denote missing information. Brazilian state abbreviations: $\mathrm{AC}=$ Acre, $\mathrm{BA}=$ Bahia, $\mathrm{ES}=$ Espírito Santo, $\mathrm{MG}=$ Minas Gerais, $\mathrm{MT}=$ Mato Grosso, $\mathrm{PA}=$ Pará, $\mathrm{PR}=$ Paraná, $\mathrm{RJ}=$ Rio de Janeiro, $\mathrm{RS}=$ Rio Grande do Sul, $\mathrm{SC}=$ Santa Catarina, and $\mathrm{SP}=$ São Paulo

\section{Discussion}

\section{Molecular support for clades}

Coussareeae are confirmed to be monophyletic and sister to a clade formed by the Psychotrieae and Spermacoceae alliances (Fig. 1), as tentatively indicated in previous studies with limited sampling, (e.g., Andersson and Rova 1999; Bremer and Eriksson 2009). This study is, however, the first to include all genera assigned to the tribe, with multiple representative accessions (except for Oreopolus and Standleya; Fig. 1; Online Resource 1). Bradea and Standleya are firmly placed in Coussareeae, as suspected by Delprete and Jardim (2012).

The tribe is resolved in three major suprageneric clades: (1) the Coussarea-Faramea clade (corresponding to Coussareeae sensu Hooker 1873), (2) the Cruckshanksia clade (corresponding to Cruckshanksieae sensu Andersson and Rova 1999, i.e., Cruckshanksia, Heterophyllaea and Oreopolus), and (3) the Coccocypselum clade (corresponding to an amended Coccocypseleae sensu Piesschaert 2000, i.e., Coccocypselum, Declieuxia, and Hindsia, with the addition of Bradea and Standleya). Of these, only the Coussarea-Faramea clade has been previously demonstrated to be monophyletic by molecular methods (e.g., Bremer and Manen 2000). Cruckshanksia, Heterophyllaea, and Oreopolus are for the first time included in the same study. Similarly, the (Coccocypselum-(Bradea-Standleya)) subclade of the Coccocypselum clade is for the first time demonstrated here.

The respective monophyly of Bradea, Coccocypselum, Coussarea, Cruckshanksia, Declieuxia, Faramea, and Heterophyllaea is for the first time demonstrated using molecular data and a systematic approach, as all previous studies have included single or few terminals per genus (none for Bradea) and not always resolved in supported monophyletic groups (e.g., Andersson and Rova 1999; Robbrecht and
Manen 2006). Within the genera represented by multiple accessions, some supported clades are formed (except in Bradea), but pending studies focused on infrageneric relationships, utilizing denser taxon and/or locus samplings we refrain from giving these infrageneric relationships undue attention.

Conflicts between topological results based on data from the different genomic compartments, e.g., due to reticulate evolution, may be more common than previously recognized (e.g., Rydin et al. 2017), but we detected no conflicting signals when visually comparing the results of the individual loci, cDNA, and rDNA analyses, i.e., there are no supported topological conflicts in the phylogenies (Online Resources 3 and 4). These findings may be consistent with the fact that most species of Coussareeae are diploid and thus unlikely the result of reticulate speciation processes such as allopolyploidization.

\section{Non-molecular support for clades}

Interestingly, structures traditionally considered to be of high diagnostic value for suprageneric lineages in Rubiaceae, such as placentation and seed coat structure, are apparently not useful in the interpretation of phylogenetic signals in Coussareeae. Contrastingly, characters derived from, e.g., fruit morphology, karyology, and pollen morphology seem to be of considerable value for diagnostics of the three main suprageneric clades (Table 1; Fig. 1). No non-molecular characters have been identified to characterize the tribe as a whole, but each major suprageneric lineage is supported by suites of diagnostic characters.

The close relationship of Heterophyllaea, Cruckshanksia, and Oreopolus (Fig. 1) is supported by several morphological traits (Tables 1,2). One potential synapomorphy for the Cruckshanksia clade is its chartaceous and loculicidal capsules (Hooker 1873; Müller Argoviensis 1881; Schumann 1891; Taylor 1996; Taylor et al. 2004). Other diagnostic characters for the clade, such as a strictly pentamerous perianth (Schumann 1891), spheroidal, 3-colporate pollen grains with simple reticulate tecta (Dessein et al. 2005), and a basic chromosome number of 11 (Kiehn 2010; only investigated for Cruckshanksia hymenodon), are probably plesiomorphic in Rubioideae, but are nonetheless useful for distinguishing suprageneric lineages within Coussareeae. The sister genera, e.g., Cruckshanksia and Oreopolus, share a similar habit (subshrubs, rarely annual herbs as opposed to shrub to small tree in Heterophyllaea; Table 1; Schumann 1891; S. Löfstrand personal observation), unwinged seeds (Heterophyllaea has winged seeds) and bright yellow corollas-a potential synapomorphy for the group (Heterophyllaea has white corollas; Table 1; Hooker 1873; Taylor 1996). In some treatments of the genera, Oreopolus has been considered to 
Table 2 Pollen morphology in Coussareeae

\begin{tabular}{|c|c|c|c|c|c|}
\hline Genus & Shape & No. of apertures & Apertures type & Annulus & Sexine sculpting \\
\hline Cruckshanksia & Spheroidal $^{\mathrm{a}}$ & $3^{\mathrm{a}}$ & Colporate $^{\mathrm{a}}$ & Absent $^{\mathrm{a}}$ & Simple reticulate ${ }^{\mathrm{a}}$ \\
\hline Bradea & Prolate-spheroidal $^{\mathrm{b}}$ & $3^{\mathrm{b}}$ & Colporate $^{\mathrm{b}}$ & Absent ${ }^{\mathrm{b}}$ & Complex reticulate ${ }_{-}^{\mathrm{b}}$ \\
\hline Coccocypselum & Spheroidal $^{\mathrm{c}}$ & $3(-4)^{c}$ & Colporate $^{\mathrm{c}}$ & Absent $^{\mathrm{a}, \mathrm{c}}$ & Complex reticulate $^{c}$ \\
\hline Declieuxia & Spheroidal $^{\mathrm{c}}$ & $3(-4)^{\mathrm{c}}$ & Colporate $^{\mathrm{c}}$ & Absent $^{\mathrm{a}, \mathrm{c}}$ & Complex reticulate $^{c}$ \\
\hline Hindsia & Spheroidal $^{c}$ & $3(-4)^{\mathrm{c}}$ & Colporate $^{c}$ & Absent $^{\mathrm{a}, \mathrm{c}}$ & Complex reticulate (or intermediate) ${ }^{\mathrm{c}}$ \\
\hline Coussarea & Oblate-suboblate $^{\mathrm{a}}$ & $2(-3)^{\mathrm{a}}$ & Porate $^{\mathrm{a}}$ & Present $^{\mathrm{a}}$ & Simple, tectate-perforate-microreticulate \\
\hline Faramea & Oblate-suboblate ${ }^{\mathrm{a}}$ & $3-4^{\mathrm{a}}$ & Porate $^{a}$ & Present $^{\mathrm{a}, \mathrm{d}}$ & Simple, rugulate ${ }^{\mathrm{a}}$ \\
\hline
\end{tabular}

Hyphens (-) denote missing information. The pollen morphology is unknown for Heterophyllaea, Oreopolus, and Standleya

${ }^{\mathrm{a}}$ Dessein et al. (2005); ${ }^{\mathrm{b}}$ Oliveira and Sobrado (2016); ${ }^{\mathrm{C}}$ Piesschaert et al. (2000); ${ }^{\mathrm{d}}$ Baker (1955)

be a member of Cruckshanksia, but they are currently segregated, based on, e.g., their capsule dehiscence patterns: from the apex into two valves in Oreopolus versus from the base into 2-5 valves in Cruckshanksia (Taylor 1996).

The clade formed by Bradea, Coccocypselum, Declieuxia, Hindsia, and Standleya (Fig. 1) is supported by some potentially synapomorphic morphological and palynological features (Tables 1,2). All genera in the clade except Coccocypselum are characterized by septicidal fruit dehiscence, even the baccate schizocarps of Declieuxia (Müller Argoviensis 1881; Schumann 1891; Jardim and Costa (2015). Septicidal dehiscence is similarly uncommon in Rubioideae (e.g., Schumann 1891), and the indehiscent fruits of Coccocypselum could be the cause of an independent reversal. Bradea, Coccocypselum, Declieuxia, and Hindsia all have pollen grains with complex reticulate tecta (Piesschaert et al. 2000; Oliveira and Sobrado 2016). The trait is somewhat poorly understood, but appears to be exceedingly rare in Rubiaceae (Dessein et al. 2005). Micromorphological studies of pollen grains from Standleya could confirm the synapomorphic nature of the trait. All members of the clade where the karyology has been studied also have a basic chromosome number of 10 (Kiehn 1995, 2010). Most Rubioideae have a basic chromosome number of 11 (Kiehn 2010), strengthening the notion of the trait being synapomorphic for the clade, but additional studies of the hitherto karyologically unexamined genera would be beneficial. Furthermore, the clade and its sister, the Coussarea-Faramea clade, are characterized by their tetramerous corollas (but mostly pentamerous in Hindsia; Müller Argoviensis 1881; Taylor 1996; Taylor et al. 2004; S. Löfstrand personal observation). Piesschaert et al. (2000) proposed "stipules bearing a central colleter-tipped awn extending to the next stipule in a distinct ridge" (paraphrased) to be a potential synapomorphy for Coccocypselum, Declieuxia, and Hindsia, previously described by Kirkbride (1976) for Declieuxia. This type of stipule has also been described for Standleya glomerulata by Jardim and Costa (2015), but they do not mention or show a stem ridge. Contrastingly, a stem ridge can be seen in the images of Oliveira and Sobrado's (2016) description of Bradea borrerioides, but they do not mention or show stipules with a central colleter-tipped awn. On herbarium specimens, the stem ridge is often prominent on Declieuxia spp. and Hindsia spp. but harder to assess on, e.g., the often slender and densely hairy Coccocypselum stems (S. Löfstrand personal observation).

The sister relationship of Coussarea and Faramea (Fig. 1) is supported by a few potentially synapomorphic morphological and palynological features: 1(-2)-seeded drupaceous fruits (one ovule is usually aborted during development; Table 1; e.g., Taylor et al. 2004); and oblate-suboblate 2-4-porate pollen grains with annuli bordering the pores and simple, tectate-microperforate or rugulate tecta (Table 2; Baker 1955; Piesschaert et al. 2000; Dessein et al. 2005). Both porate pollen grains and apertures bordered by annuli are uncommon in Rubiaceae, indicating that the characters are likely synapomorphic for the clade (Dessein et al. 2005). Similarly, their drupaceous, single-seeded fruits with thin endocarps surrounding the seeds clearly distinguish them from most other Rubiaceae with drupaceous fruits (e.g., Taylor et al. 2004). They are additionally characterized by, e.g., their tetramerous corollas (together with the Coccocypselum clade; Table 1).

\section{Age and geographic ranges}

Historical biogeography and node ages of Coussareeae have never been thoroughly analyzed. The clade emerged in the Paleocene (63-59 Ma; Bremer and Eriksson 2009; Wikström et al. 2015), which corresponds well with the fossil record of Faramea pollen in Mesoamerica from the Eocene and onwards (Graham 2009). The three extant suprageneric clades were arguably already distinct at this time; the alternative would be far less parsimonious, requiring that the most recent common ancestor of the tribe had Faramea-type pollen (oblate-suboblate, porate grains with annuli) and two independent reversals to the apparently plesiomorphic state of spheroidal, colporate 
grains lacking annuli (Table 1; Dessein et al. 2005) took place. Fossil Faramea pollen has also been described in sediments from the Late Pleistocene in southeastern Brazil (ca. 24-15 ka), i.e., in one of the presumed stable areas of Atlantic forest during the last glacial maximum (Clark et al. 2009; Mello Martins 2011; Gonçalves de Freitas et al. 2013). No fossils have been described in the other genera of Coussareeae.

The three suprageneric clades (Fig. 1) show some general patterns in their extant distributions. Members of the Cruckshanksia clade are native to different biomes in the Andes of western South America (Hooker 1873; Taylor 1996; Govaerts et al. 2018). Heterophyllaea is native to the cool subtropical highlands of northern Argentina, Bolivia, and southern Peru (Hooker 1873; Flora Argentina 2018; Tropicos 2018). Cruckshanksia and Oreopolus are native to the "arid diagonal" (predominately cool and arid climate) with Cruckshanksia found from central Chile to northwestern Argentina and Oreopolus from central to southern Argentina (Taylor 1996; Tropicos 2018). The Coccocypselum clade on the other hand has a clear center of diversity in southeastern Brazil; Bradea, Hindsia, and Standleya are all endemic to the region, with Hindsia growing primarily in montane, sandy Cerrado (Steyermark 1978; Di Maio 1996), whereas Bradea and Standleya grow in partial to full sun on well-drained, rocky outcrops in the Atlantic Rainforest (Jardim and Costa 2015; Oliveira and Sobrado 2016). Coccocypselum and Declieuxia are more widely distributed (southeastern South America to southern Mexico; Tropicos 2018), but most species in both genera are endemic to southeastern Brazil; both genera grow in partial to full sun, with the former widespread in the Atlantic Rainforest biomes and the latter primarily on savannas (Kirkbride 1976; Robbrecht 1993; Costa and Mamede 2002; Costa 2007). Coussarea and Faramea are both widespread in the Neotropics (Tropicos 2018), mostly growing in various forest biomes, ranging from seasonally dry forests through swampy lowland rainforests to highland cloud forests (Müller Argoviensis 1881; Burger and Taylor 1993; Taylor et al. 2004). Both genera show great species diversity and are found from tropical Mesoamerica along the eastern border of the Andes to western-central Bolivia, but also in the Guyana region in northeastern South America and in the Atlantic Rainforest of southeastern Brazil to Paraguay and northeastern Argentina (Tropicos 2018; Govaerts et al. 2018).

\section{A note on classifications}

As previously discussed by both Bremer and Manen (2000) and Robbrecht and Manen (2006), Coussareeae as currently delimited is morphologically heterogeneous, and despite a better understanding of their phylogenetic relationship, extensive herbarium sheets inspections, and a broad literature review, they remain difficult to characterize as one entity by non-molecular means. The three major suprageneric lineages are, contrastingly, easily distinguished by both gross morphology, karyology, and/or pollen morphology. This brings to question at which rank the clade should be recognized. On the one hand, there is ample evidence to support each of the major suprageneric clades, two of which have a history of tribal status in their own right: the CoussareaFaramea clade $=$ Coussareeae sensu Hooker (1873) and the Cruckshanksia clade $=$ Cruckshanksieae sensu Andersson and Rova (1999). The Coccocypselum clade could be viewed as an amended version of Coccocypseleae sensu Piesschaert et al. (2000). On the other hand, detailed micromorphological studies (e.g., light microscopy of microtome sections and scanning electron microscopy), ontogenetic studies, and further palynological studies may reveal further synapomorphies. An example where studies such as these revealed multiple synapomorphies for a seemingly morphologically disparate clade is the (Sarraceniaceae-(Actinidiaceae-Roridulaceae)) clade in Ericales (Löfstrand and Schönenberger 2015; Löfstrand et al. 2016). Hence, the three major suprageneric clades could be recognized at the tribal level, but we refrain from performing any nomenclatural changes at present, pending detailed micromorphological studies of Coussareeae as currently delimited.

This study further allows us to comment on the current infrageneric classifications of Declieuxia (Müller Argoviensis 1881; Kirkbride 1976) and Faramea (Müller Argoviensis 1881). Within Declieuxia, the informal infrageneric sections delimited by Müller Argoviensis (1881) are apparently untenable, but difficult to assess in detail with our taxon sampling; for example, D. juniperina, D. saturejoides, $D$. spergulifolia, and $D$. aspalathoides were considered to belong to one section, based on their single-veined, narrow leaves, but they do not form a clade in our analyses. Conversely, the penninerved, broadly lanceolate-leaved $D$. cacuminis forms a sister relationship with $D$. aspalathoides and the 3-5-nerved, narrow-leaved $D$. passerina is closely related to D. juniperina. Similarly, the characters investigated by Kirkbride (1976; e.g., habit and shift to homostyly) in the most current revision of the genus show no apparent phylogenetic signal when viewed in the light of our molecular-based phylogeny (Fig. 1). Note, however, that Kirkbride (1976) opted not to organize Declieuxia in formal sections. Within Faramea, the "Tetramerium clade" largely corresponds to Faramea sect. Tetramerium (characterized by, e.g., two to threeparted flowering branches; Müller Argoviensis 1881), but in that classification, F. affinis is assigned to Faramea sect. Homoclados (characterized by, e.g., pronounced, petaloid calyx limbs; Müller Argoviensis 1881) and F. pachyantha to Faramea sect. Hypochasma (characterized by, e.g., transversal fissured in the seed coat; Müller Argoviensis 1881). 
No other species sampled for this study are treated in the classification, and none of the characters utilized to delimit the sections seems to reflect any phylogenetic signal. Hence, the infrageneric classification in Faramea set out by Müller Argoviensis (1881) is untenable.

\section{Conclusions}

Coussareeae are a monophyletic group consisting of three major suprageneric clades, two of which have not previously been demonstrated in a single analysis. The Cruckshanksia clade (Heterophyllaea-(Cruckshanksia-Oreopolus)) is sister to the Coccocypselum clade ((Coccocypselum-(BradeaStandleya))-(Declieuxia-Hindsia)) and the CoussareaFaramea clade. All genera represented by more than one terminal are supported as monophyletic. The understudied genera Bradea and Standleya are closely related and sister to Coccocypselum.

Coussareeae are difficult to define morphologically and inhabit a wide array of ecological niches and geographic regions. However, the clade formed by the Coccocypselum clade and the Coussarea-Faramea clade is characterized by (relatively) consistently tetramerous corollas, a useful character within Coussareeae (albeit not unique for a suprageneric clade within Rubioideae). Additionally, the three major suprageneric clades included in Coussareeae are all readily distinguished by suites of morphological, palynological, and karyological features, some of which appear to be synapomorphic.

The three major suprageneric clades additionally show some general patterns in their distribution: The Cruckshanksia clade is restricted to different biomes in the Andes, the Coccocypselum clade is widespread, but with a clear center of biodiversity in southeastern Brazil, and the CoussareaFaramea clade is widespread in Neotropical forests.

Acknowledgements We are grateful to the directors and curators of the AAU, GB, CR, K, MO, NYBG, S, and UPS herbaria for access to herbarium specimens, to Charlotte M. Taylor (Missouri Botanical Garden, St. Louis, USA) for helpful insights on the relationships and biology in the group, and for grants to CR from the Royal Swedish Academy of Sciences, Stockholm University, and the Swedish Research Council. We would also like to thank the two anonymous reviewers for their proposed manuscript improvements.

Funding The project was funded by grants to C.R. from the Royal Swedish Academy of Sciences, Stockholm University, and the Swedish Research Council.

\section{Compliance with ethical standards}

Conflict of interest The authors declare that they have no conflict of interest.
Open Access This article is distributed under the terms of the Creative Commons Attribution 4.0 International License (http://creativeco mmons.org/licenses/by/4.0/), which permits unrestricted use, distribution, and reproduction in any medium, provided you give appropriate credit to the original author(s) and the source, provide a link to the Creative Commons license, and indicate if changes were made.

\section{Information on electronic supplementarymaterial}

Online Resource 1. Taxon sampling and sequence accession numbers. Online Resource 2. Alignment files in interleaved Nexus format. Online Resource 3. 50\% Bayesian majority rule consensus cladogram of cDNA.

Online Resource 4. 50\% Bayesian majority rule consensus cladogram of rDNA.

\section{References}

Andersson L, Rova JH (1999) The rps16 intron and the phylogeny of the Rubioideae (Rubiaceae). Pl Syst Evol 214:161-166. https:// doi.org/10.1007/BF00985737

Baker HG (1955) Pollen dimorphism in the Rubiaceae. Evolution 10:23-31. https://doi.org/10.1111/j.1558-5646.1956.tb02826.x

Baldwin BG, Markos S (1998) Phylogenetic utility of external transcribed spacer (ETS) of 18S-26S rDNA: congruence of ETS and ITS trees of Calycadenia (Compositae). Molec Phylogen Evol 10:449-463. https://doi.org/10.1006/mpev.1998.0545

Bawa KS, Beach JH (1983) Self-incompatibility systems in the Rubioideae (Rubiaceae). Amer J Bot 70:1281-1288. https://doi. org/10.1002/j.1537-2197.1983.tb07917.x

Bremekamp CEB (1952) A re-examination of Cesalpino's classification. Acta Bot Neerl 1:580-593. https://doi. org/10.1111/j.1438-8677.1953.tb00033.x

Bremekamp CEB (1966) Remarks on the position, the delimitation and the subdivision of the Rubiaceae. Acta Bot Neerl 15:1-33. https ://doi.org/10.1111/j.1438-8677.1966.tb00207.x

Bremer B (1996) Phylogenetic studies within Rubiaceae and relationships to other families based on molecular data. Opera Bot Belg $7: 33-50$

Bremer B, Eriksson T (2009) Time tree of Rubiaceae and dating the family, subfamilies, and tribes. Int J P1 Sci 170:766-793. https:// doi.org/10.1086/599077

Bremer B, Manen JF (2000) Phylogeny and classification of the subfamily Rubioideae (Rubiaceae). Pl Syst Evol 225:43-72. https:// doi.org/10.1007/BF00985458

Bremer B, Bremer K, Heidari N, Erixon P, Olmstead RG, Anderberg AA, Källersjö M, Barkhordarian E (2002) Phylogenetics of asterids based on 3 coding and 3 non-coding chloroplast DNA markers and the utility of non-coding DNA at higher taxonomic levels. Molec Phylogen Evol 24:274-301. https://doi.org/10.1016/ S1055-7903(02)00240-3

Brummit RK (2001) World geographical scheme for recording plant distributions, 2nd edn. Hunt Institute, Pittsburgh

Burger W, Taylor CM (1993) Flora costaricensis Family \#202 Rubiaceae. Fieldiana Bot 33:1-333

Clark PU, Dyke AS, Shakun JD, Carlsson AE, Clark J, Wohlfarth B, Mitrovica JX, Hostetler SW, McCabe AM (2009) The last glacial 
maximum. Science 325:710-714. https://doi.org/10.1126/scien ce. 1172873

Corrêa AM, Forni-Martins ER (2004) Chromosomal studies of species of Rubiaceae (A. L. de Jussieu) from the Brazilian cerrado. Caryologica 57:250-258. https://doi.org/10.1080/00087114.2004.10589 400

Costa CB (2007) A new species of Coccocypselum P.Br. (Rubiaceae) from southeast Bahia (Brazil). Kew Bull 62:623-627

Costa CB, Mamede MCH (2002) Sinopse do gênero Coccocypselum P. Browne (Rubiaceae) no estado de São Paolo, Brasil. Biota Neotrop 3:1-14. https://doi.org/10.1590/S1676-06032002000100006

Darriba D, Taboada GL, Doallo R, Posada D (2012) jModelTest 2: more models, new heuristics and parallel computing. Nature Meth 9:772. https://doi.org/10.1038/nmeth.2109

Delprete PG, Jardim JG (2012) Systematics, taxonomy and floristics of Brazilian Rubiaceae: an overview about the current status and future challenges. Rodriguésia 63:101-128. https://doi. org/10.1590/S2175-78602012000100009

Dessein S, Ochoterena H, De Block P, Lens F, Robbrecht E, Schols P, Smets E, Vinckier S, Huysmans S (2005) Palynological characters and their phylogenetic signal in Rubiaceae. Bot Rev (Lancaster) 71:354-414. https://doi.org/10.1663/0006-8101

Di Maio FR (1996) Revisão taxononômica do Gênero Hindsia Bentham (Rubiaceae, Hedyotidae). Arch Jard Bot Rio de Janeiro 34:51-92

Edgar RC (2004) MUSCLE: multiple sequence alignment with high accuracy and high throughput. Nucl Acids Res 32:1792-1797. https://doi.org/10.1093/nar/gkh340

Erixon P, Svennblad B, Britton T, Oxelman B (2003) Reliability of Bayesian posterior probabilities and bootstrap frequencies in phylogenetics. Syst Biol 52:665-673. https://doi.org/10.1080/10635 150390235485

Flora Argentina (2018) Online version of Flora Fanerogámica Argentina (1995-2007). Available at: http://www.floraargentina.edu.ar. Accessed 22 Oct 2018

Gelman A, Rubin DB (1992) Inference from iterative simulation using multiple sequences. Stat Sci 7:457-511. https://doi.org/10.1214/ ss/1177011136

Gonçalves de Freitas A, de Araujo Carvalho M, Barbieri Ferreira Mondeonça C, Gonçalves Esteves V (2013) Pollen grains in quaternary sediments from the Campos Basin, state of Rio de Janeiro, Brazil: Core BU-91-GL-05. Acta Bot Brasil 27:761-772. https:// doi.org/10.1590/S0102-33062013000400016

Govaerts R, Ruhsam M, Andersson K, Robbrecht E, Davis A, Schanzer I, Sonke B (2018) World checklist of Rubiaceae; facilitated by the Royal Botanic Gardens, Kew. Available at: http://wcsp.scien ce.kew.org/home.do. Accessed 22 Oct 2018

Graham A (2009) Fossil record of the Rubiaceae. Ann Missouri Bot Gard 96:90-108. https://doi.org/10.3417/2006165

Hooker JD (1873) Rubiaceae. In: Bentham G, Hooker JD (eds) Genera Plantarum: ad exemplaria imprimis in Herberiis Kewensibus servata definite, vol. 2, Sistens dicoteledonum gamopetalaum ordines VI; Caprifoliaceas-Compositas, pt. 1. Lowell Reeve and co, London, pp 7-151

Jardim JG, Costa CB (2015) A new species of Standleya (Rubiaceae, Coussareeae) with a new record from Bahia, Brazil. Phytotaxa 206:74-78. https://doi.org/10.11646/phytotaxa.206.1.10

Jardim JG, Zappi DC (2008) Two new species of Faramea (Rubiaceae, Coussareeae) from eastern Brazil. Novon 18:67-71

Kårehed J, Bremer B (2007) The systematics of Knoxieae (Rubiaceae): molecular data and their taxonomic consequences. Taxon 56:1051-1076. https://doi.org/10.2307/25065904

Kearse M, Moir R, Wilson A, Stones-Havas S, Cheung M, Sturrock S, Buxton S, Cooper A, Markowitz S, Duran C, Thierer T, Ashton B, Mentjies P, Drummond A (2012) Geneious Basic: an integrated and extendable desktop software platform for the organization and analysis of sequence data. Bioinformatics 28:1647-1649. https:// doi.org/10.1093/bioinformatics/bts199

Kiehn M (1995) Chromosome survey of the Rubiaceae. Ann Missouri Bot Gard 82:398-408. https://doi.org/10.2307/2399890

Kiehn M (2010) Chromosomes of Neotropical Rubiaceae. I: Rubioideae. Ann Missouri Bot Gard 97:91-105. https://doi. org/10.3417/2007115

Kirkbride JH (1976) A revision of the genus Declieuxia (Rubiaceae). Mem New York Bot Gard 28:1-87

Löfstrand SD, Schönenberger J (2015) Comparative floral structure and systematics in the sarracenioid clade (Actinidiaceae, Roridulaceae and Sarraceniaceae) of Ericales. Bot J Linn Soc 178:1-46. https ://doi.org/10.1111/boj.12266

Löfstrand SD, von Balthazar M, Schönenberger J (2016) Early floral development and androecium organization in the sarracenioid clade (Actinidiaceae, Roridulaceae and Sarraceniaceae) of Ericales. Bot J Linn Soc 180:295-318. https://doi.org/10.1111/ boj. 12382

Macbride JF (1936) Flora of Peru part VI. Field Museum of Natural History, Chicago

Maddison WP, Maddison DR (2017) Mesquite: a modular system for evolutionary analysis. Version 3.31. Available at: http://mesqu iteproject.org. Accessed 14 Feb 2018

Maruyama PK, Amorim FW, Oliveira PE (2010) Night and day service: distyly and mixed pollination system in Faramea cyanea (Rubiaceae). Flora 205:818-824. https://doi.org/10.1016/j.flora .2010 .01 .004

Mello Martins F (2011) Historical biogeography of the Brazilian Atlantic forest and the Carnaval-Moritz model of Pleistocene refugia: what do phylogeographical studies tell us? Biol J Linn Soc 104:499-509. https://doi.org/10.1111/j.1095-8312.2011.01745.x

Müller Argoviensis J (1881) Rubiaceae, pt. 5. In: Martius CFP, Eichler AG, Urban I (eds) Flora Brasiliensis, vol. 6. Apud. Frid. Fleischer in Comm., Leipzig, pp 1-470

Negrón-Ortiz V, Watson LE (2002) Molecular phylogeny and biogeography of Erithalis (Rubiaceae), an endemic of the Caribbean basin. P1 Syst Evol 234:71-83. https://doi.org/10.1007/s0060 6-002-0192-2

Oliveira JA (2012) Filogenia e revisão taxônomica de Bradea Standl. e Standleya Brade (Rubiaceae). MSc Thesis, Botanical Garden of Rio de Janeiro, Rio de Janeiro

Oliveira JA, Sobrado SV (2016) Bradea borrerioides (Rubiaceae), a new species from Brazilian inselbergs. Phytotaxa 243:83-90. https ://doi.org/10.11646/phytotaxa.243.1.4

Oxelman B, Lidén M, Berglund D (1997) Chloroplast rps16 intron phylogeny of the tribe Silaneae (Caryophyllaceae). Pl Syst Evol 206:393-401. https://doi.org/10.1007/BF00987959

Piesschaert F, Huysmans S, Jaimes I, Robbrecht E, Smets E (2000) Morphological evidence for an extended tribe-Coccocypseleae (Rubiaceae-Rubioideae). Pl Biol (Stuttgart) 2:536-546. https:// doi.org/10.1055/s-2000-7473

Robbrecht E (1988) Tropical woody Rubiaceae. Opera Bot Belg $1: 1-273$

Robbrecht E (1993) Coccocypselum guianense. Bot Mag 10:76-80. https://doi.org/10.1111/j.1467-8748.1993.tb00021.x

Robbrecht E, Manen J-F (2006) The major evolutionary lineages of the coffee family (Rubiaceae, angiosperms); combined analysis (nDNA and cpDNA) to infer the position of Coptosapelta and Luculia, and supertree construction based on $r b c \mathrm{~L}, r p s 16$, $t r n \mathrm{~L}-$ $t r n \mathrm{~F}$ and $a t p \mathrm{~B}-r b c \mathrm{~L}$ data; a new classification in two subfamilies, Cinchonoideae and Rubioideae. Syst Geogr P1 76:85-146. https:// doi.org/10.2307/20649700

Ronquist F, Teslenko M, van den Mark P, Ayres DL, Darling A, Höhna S, Larget B, Liu L, Suchard MA, Huelsenbeck JP (2012) MrBayes v. 3.2: efficient Bayesian phylogenetic inference and model choice 
across a large model space. Syst Biol 61:339-442. https://doi. org/10.1093/sysbio/sys029

Rydin C, Kainulainen K, Razafimandimbison SG, Smedmark JEE, Bremer B (2009a) Deep divergences in the coffee family and the systematic position of Acranthera. Pl Syst Evol 278:101-123. https://doi.org/10.1007/s00606-008-0138-4

Rydin C, Razafimandimbison SG, Khodabandeh A, Bremer B (2009b) Evolutionary relationships in the Spermacoceae alliance (Rubiaceae) using information from six molecular loci: insights into systematic affinities of Neohymenopogon and Mouretia. Taxon 58:793-810. https://doi.org/10.5167/uzh-25509

Rydin C, Wikström N, Bremer B (2017) Conflicting results from mitochondrial genomic data challenge current views of Rubiaceae phylogeny. Amer J Bot 104:1522-1532. https://doi.org/10.3732/ ajb. 1700255

Schumann K (1891) Rubiaceae. In: Engler A, Prantl K (eds) Die natürlichen Pflanzenfamilien nebst ihren Gattungen und wichtigeren Arten; insbesondere den Nutzpflanzen, vol. 4. Verlag von Willhelm Engelmann, Leipzig, pp 1-194

Stamatakis A (2014) RAxML version 8: a tool for phylogenetic analysis and post-analysis of large phylogenies. Bioinformatics 1:13121313. https://doi.org/10.1093/bioinformatics/btu033

Steyermark JA (1978) New Rubiaceae from the Brazilian Planalto. Brittonia 30:34-38. https://doi.org/10.2307/2806454

Taberlet P, Gielly L, Pautou G, Bouvet J (1991) Universal primers for amplification of three non-coding regions of chloroplast DNA. Pl Molec Biol 17:1105-1109. https://doi.org/10.1007/BF00037152

Taylor CM (1996) Taxonomic revision of Cruckshanksia and Oreopolus (Rubiaceae: Hedyotideae). Ann Missouri Bot Gard 83:461479. https://doi.org/10.2307/2399989
Taylor CM, Steyermark JA, Delprete PG, Vincentini A, Cortés R, Zappi D, Persson C, Bestetti Costa C, Araujo da Anunciação E (2004) Rubiaceae. In: Steyermark JA, Berry PE, Yatskievych K, Holst BK (eds) Flora of the Venezuelan Guayana, vol. 8: Poaceae-Rubiaceae. Missouri Botanical Garden Press, Saint Louis, pp 497-847

Tropicos (2018) Missouri botanical garden. Available at: http://www. tropicos.org. Accessed 22 Oct 2018

Verdcourt B (1958) Remarks on the classification of the Rubiaceae. Bull Jard Bot État Brux 28:209-280. https://doi. org/10.2307/3667090

White TJ, Wallace RS, Taylor J (1990) Amplification and direct sequencing of fungal ribosomal RNA genes for phylogenies. In: Innis M, Gelfand D, Sninsky J, White TJ (eds) PCR protocols: a guide to methods and amplifications. Academic Press, San Diego, pp 1-46

Wikström N, Kainulainen K, Razafimandimbison SG, Smedmark JEE, Bremer B (2015) A revised time tree of the asterids: establishing a temporal framework for evolutionary studies of the coffee family (Rubiaceae). PLoS One 11:e0157206. https://doi.org/10.1371/ journal.pone.0157206

Publisher's Note Springer Nature remains neutral with regard to jurisdictional claims in published maps and institutional affiliations. 